\title{
Configuration of channel bars in Černá Opava River as a consequence of flooding in September 2007
}

\author{
MAREK KŘÍǏEK \\ Charles University in Prague, Faculty of Science, \\ Department of Physical Geography and Geoecology
}

\begin{abstract}
The article deals with changes of setting of channel bars which originate from the overbank flooding events. Channel bars carry information about a flow behavior during and out of flooding. They characterize processes inside the river channel. Characteristics of bars, (location of the channel, length, width of bars, granularity, gradation setting etc.) as well as their changes during the flood are described by statistical methods (ANOVA, correlation). Correlation matrix detecting relations between all studied characteristics of channel bars before and after the flooding was created. Causes of these changes or stability of given characteristics are analyzed in the discussion. During the September 2007 flood on Černá Opava river a number of channel bars increased, the existing accumulations particularly channel bars near bends (for example scroll bars or point bars) became larger. Channel bars got connected with the banks due to their enlargement after the flood. On the contrary, accumulations (lateral bars) placed further from bends were reduced. Faster and more complicated flow during the flood enables creation of new bars with inverse gradation.
\end{abstract}

Key words: channel bars - floodplain - flood - fluvial processes - Černá Opava River

\section{Introduction}

Bars represent fluvial deposits in the area of the river channel. They typically occur in areas where accumulation processes of the stream are higher. Thus, bars predicate about behavior of the stream in a given sector of the channel (Rosgen 1994; Bridge 2003; Křížek 2007a). An array of authors pursued general study of fluvial deposits (Schumm, S. A. 1985; Hey, Thorne 1986; Hrádek 1999; Garcia, Laronne, Sala 2000; Barry 2004; sensu Dollar, 2004; sensu Hardy, 2006), but changes of their location and their arrangement after the flood were not studied sufficiently so far (Popov 1962 in Schumm 2005; Ferguson 1994; Martin 2003) whereas situation after the flood was recorded on Czech rivers till this time (Hrádek 2002, 2005; Kř́žek 2003, 2007b). Generally there are only a few studies which examine state of channel bars immediately before and after the flood. For example Lana-Renault, Reguiés (2007) monitored relation of bedload transport and discharge during floods in detail but on a few reference profiles only. Monitoring of location and arrangement changes of channel bars before and after a flood enables to describe similarity or dissimilarity of fluvial processes influence during extreme and normal water-level stage (sensu Batalla, 
Martín-Vide 2000). The aim of this article is to characterize basic spatial distribution and qualitative changes of channel bars (created before the flood) in Černá Opava River during standard flow and after the September 2007 flood.

Černá Opava River is the longest out of three sources of Opava River, it has gravelly stream. The research was done in $13.5 \mathrm{~km}$ long sector where Černá Opava River has a well-developed floodplain from a bridge under Přední Jestřábí (744.9 m a.s.l.) to its confluence with Střední Opava River in Vrbno pod Pradědem (540 m a.s.l.). The valley of Černá Opava River is situated on boundary of three geomorphological units the Hornoopavská hornatina Mts. in the north and the west, the Heřmanovické hřbety Ridges in the north-east and the Holčovická vrchovina Hihgland in the east (Demek /editor/ et al. 1986). These units are a part of geomorphologic subsystems: the Medvědská hornatina Mts. (the Hornoopavská hornatina Mts.), actually the Rejvízská hornatina Mts. (the Heřmanovické hřbety Ridges) and the Hynčická hornatina Mts. (the Holčovická vrchovina Highland) which belong to geomorphologic systems of the Hrubý Jeseník Mts. (the Medvědská hornatina Mts.) and the Zlatohorská vrchovina Highland (the Rejvízská hornatina Mts. and the Hynčická hornatina Mts.) (Demek /editor/ et al. 1986). Upper and middle parts of the Černá Opava valley and its wider neighbourhood are built of metamorphic rocks (mainly orthogneiss, migmatite, phyllite and mica schist). Thick regolith covers of valley slopes were formed during the cold Pleistocene periods (Czudek 1997). The middle section of the Černá Opava River Valley has remnants of braided system formed under Pleistocene climatic conditions (Klimek, Zielińska 2006). Lower part of this valley (from Josefský hamr to Vrbno pod Pradědem) is built of greywackes, slates, quartzites and limestones. Major part of the studied channel of Černá Opava River is in natural or near-natural state except for the lower reach where the river runs through Mnichov and Vrbno pod Pradědem. In this part Černá Opava River has anthropogenic reinforced banks and partly consolidated bottom of its channel. Remains of ironmills and sawmills and their mill-races which were here in $17^{\text {th }}$ century already can be found in the middle and lower part of the river.

Numerous natural erosion cuttings in floodplain of Černá Opava River uncover sedimentary records supporting older historical floods (Polách, Gába 1998; Klimek, Zielińska 2006). The last large flood which affected the study area before 2007 occurred in 1997 (Hladný et al. 1998), its general geomorphologic characteristics in northern Moravia were described by Hrádek (1999). An important flood event also occurred at the turn of the $19^{\text {th }}$ and $20^{\text {th }}$ century, presumably in 1903 (Polách, Gába 1998), during which parts of channel on nearby Bílá Opava River were changed of the course of a river (avulsion) and many islands that are outside the channel now (Klimek et al. 2003) were created. During the 2007 flood avulsion channels were also created on Černá Opava River. The most important avulsion channel was created above bridge over Černá Opava River between Josefský hamr and Mnichov.

\section{Methods}

Primary source of spatial and other qualitative and quantitative characteristics of channel bars was field geomorphologic research assigned in the studied area in two 
campaigns: at the end of July 2007 (before the flood with culmination on $7^{\text {th }}$ September 2007) and at the beginning of October 2007 (after the flood with culmination on $7^{\text {th }}$ September 2007). Water level was similar in both mapping campaigns. To determine lengths rates sliding tape rule and laser distance meter LaserAce were used. Position information were drawn into basic topographic maps (in scale 1:10 000). Spatial information about channel bars and their other characteristics were processed in ArcGIS 9.2 (ESRI 2006) and then statistically analyzed in STATISTICA 8 Standard CZ (StatSoft 2003). Density of bars was calculated in GIS using the cell of $5 \mathrm{~m}$ and radius $100 \mathrm{~m}$.

Qualitative and quantitative characteristics of channel bars were evaluated based on ratio graphs created in MS Office Excel 2003 (Microsoft 2003). Input data for ratio graphs were created by conversion of absolute number of cases in single categories into percentage representation within a chosen group of channel bars (see below, Table 1). Percentage contribution of every category for different type of channel bars was compared for these modified data. In order to find out changes in qualitative characteristics of channel bars as a consequence of the flood, these characteristics of bars (which existed before the flood /"bars before flood"/, which existed before and after the flood /"permanent" bars/, which emerged after the flood /"new bars after flood"/, which stayed in the channel after the flood /"all bars after flood"/) were compared. For "permanent" bars, two values of qualitative characteristics - before and after the flood ("permanent bars before flood", "permanent bars after flood") were taken into account.

Table 1: Number and percentage representation of channel bars according to their position in the channel and their classifications to groups of bars

\begin{tabular}{|c|c|c|c|c|c|c|c|c|c|c|}
\hline Position & $\begin{array}{c}\text { Bars } \\
\text { before } \\
\text { flood }\end{array}$ & $\begin{array}{c}\text { Permanent } \\
\text { bars } \\
\text { (before } \\
\text { flood) }\end{array}$ & $\begin{array}{c}\text { Permanent } \\
\text { bars } \\
\text { (after } \\
\text { flood) }\end{array}$ & $\begin{array}{c}\text { New } \\
\text { bars } \\
\text { after } \\
\text { flood }\end{array}$ & $\begin{array}{c}\text { All } \\
\text { bars } \\
\text { after } \\
\text { flood }\end{array}$ & $\begin{array}{c}\text { Bars } \\
\text { before } \\
\text { flood } \\
\%\end{array}$ & $\begin{array}{c}\text { Permanent } \\
\text { bars } \\
\text { before } \\
\text { (flood) } \%\end{array}$ & $\begin{array}{c}\text { Permanent } \\
\text { bars } \\
\text { (after } \\
\text { flood) } \%\end{array}$ & $\begin{array}{c}\text { New } \\
\text { bars } \\
\text { after } \\
\text { flood \% }\end{array}$ & $\begin{array}{c}\text { All bars } \\
\text { after } \\
\text { flood } \\
\%\end{array}$ \\
\hline 1 & 12 & 9 & 8 & 9 & 17 & 12.77 & 11.54 & 10.26 & 12.16 & 11.18 \\
\hline 2 & 5 & 3 & 1 & 4 & 5 & 5.32 & 3.85 & 1.28 & 5.41 & 3.29 \\
\hline 3 & 7 & 6 & 5 & 9 & 14 & 7.45 & 7.69 & 6.41 & 12.16 & 9.21 \\
\hline 4 & 6 & 5 & 2 & 8 & 10 & 6.38 & 6.41 & 2.56 & 10.81 & 6.58 \\
\hline 5 & 10 & 9 & 7 & 8 & 15 & 10.64 & 11.54 & 8.97 & 10.81 & 9.87 \\
\hline 12 & 17 & 13 & 13 & 9 & 22 & 18.09 & 16.67 & 16.67 & 12.16 & 14.47 \\
\hline 13 & 4 & 4 & 9 & 7 & 16 & 4.26 & 5.13 & 11.54 & 9.46 & 10.53 \\
\hline 14 & 0 & 0 & 6 & 1 & 7 & 0 & 0 & 7.69 & 1.35 & 4.61 \\
\hline 15 & 2 & 2 & 1 & 0 & 1 & 2.13 & 2.56 & 1.28 & 0 & 0.66 \\
\hline 23 & 7 & 6 & 2 & 1 & 3 & 7.45 & 7.69 & 2.56 & 1.35 & 1.97 \\
\hline 24 & 6 & 5 & 1 & 0 & 1 & 6.38 & 6.41 & 1.28 & 0 & 0.66 \\
\hline 25 & 1 & 1 & 2 & 1 & 3 & 1.06 & 1.28 & 2.56 & 1.35 & 1.97 \\
\hline 34 & 4 & 3 & 2 & 1 & 3 & 4.26 & 3.85 & 2.56 & 1.35 & 1.97 \\
\hline 35 & 5 & 5 & 8 & 5 & 13 & 5.32 & 6.41 & 10.26 & 6.76 & 8.55 \\
\hline 45 & 8 & 7 & 11 & 11 & 22 & 8.51 & 8.97 & 14.10 & 14.86 & 14.47 \\
\hline
\end{tabular}


Pearson correlation of all attributes was applied only to those channel bars which existed before and after the floods ("permanent" bars) in order to achieve homogenous and comparable results. In the group of all bars Pearson correlation was defined along with basic quantitative continuous characteristics of channel bars (see bellow: width of the channel, length and width of the bar, distance "before and behind" bends, distance from the upper (beginning) of the floodplain. Significance of correlation coefficients was tested by t-test with significance level 0.05 . Power of association (sensu Hendl 2004; small 0.1-0.3, middle 0.3-0.7, large 0.7-1.0) was determined according to the power of absolute value of correlation coefficient ( $r$ ).

Qualitative changes of "bars before the flood and after the flood" were characterized by the analysis of variation (one-way ANOVA), tested by F-test with indicated significance level p. This method was applied to all channel bars and then specially to "bars before the flood". Following attributes were surveyed for each bar: a) width of the channel in the place where the bar is situated; b) distance of center of the bar with regard to preceding and following channel bends; c) position within the channel which was for this purpose divided into 5 sections in cross profile of the channel (the first section lies at left bank and the fifth section at right bank); in case the bar is located within more sections it is marked by compound figures of the border sections for example a bar placed in sections 1 and 2 is marked 12; a bar placed in sections 2, 3 and 4 is marked 24; d) length of bar, which is a dimension parallel to direction of the flow; e) width, which is a dimension orthogonal to the length; f) connection with the bank defined whether the bar is connected with the bank or not; g) character of material: sandy, gravel or combined; h) gradation which described configuration of sediments and their possible sorting according to the size (Křížek 2007b); normal gradation - with fluvial sediment refining along the stream; inverse gradation - fine components are placed first then amount of coarse-grain particles increases; channel bar without gradation where gradation was not evident; i) coverage of the channel bar by vegetation, monitored whether it is without vegetation, partly covered by grass, bushes or trees, these characteristics show time stability - time of existence of chosen channel bar; j) distance from the upper end of floodplain.

\section{Results}

\section{Density and changes between groups of channel bars}

During both mapping campaigns, 168 channel bars were identified in the studied area. 94 channel bars were found before the flood (78 of them were left after the flood) and 74 emerged after the flood. In total there were 152 channel bars after the flood. Channel bars which were created before the flood are not laid out evenly. It is the same for channel bars created after the flood. The average density of channel bars per $\mathrm{km}^{2}$ created before the flood is 0.417 (maximum 350.141; standard deviation 6.307), average density of channel bars which were created after the flood is 0.404 of bars per $\mathrm{km}^{2}$ (maximum 222.817; standard deviation 5.800). The highest density of bars before flood (Fig. 1) is reached in bends under Zámecký vrch Hill by the mouth of a sinistral 


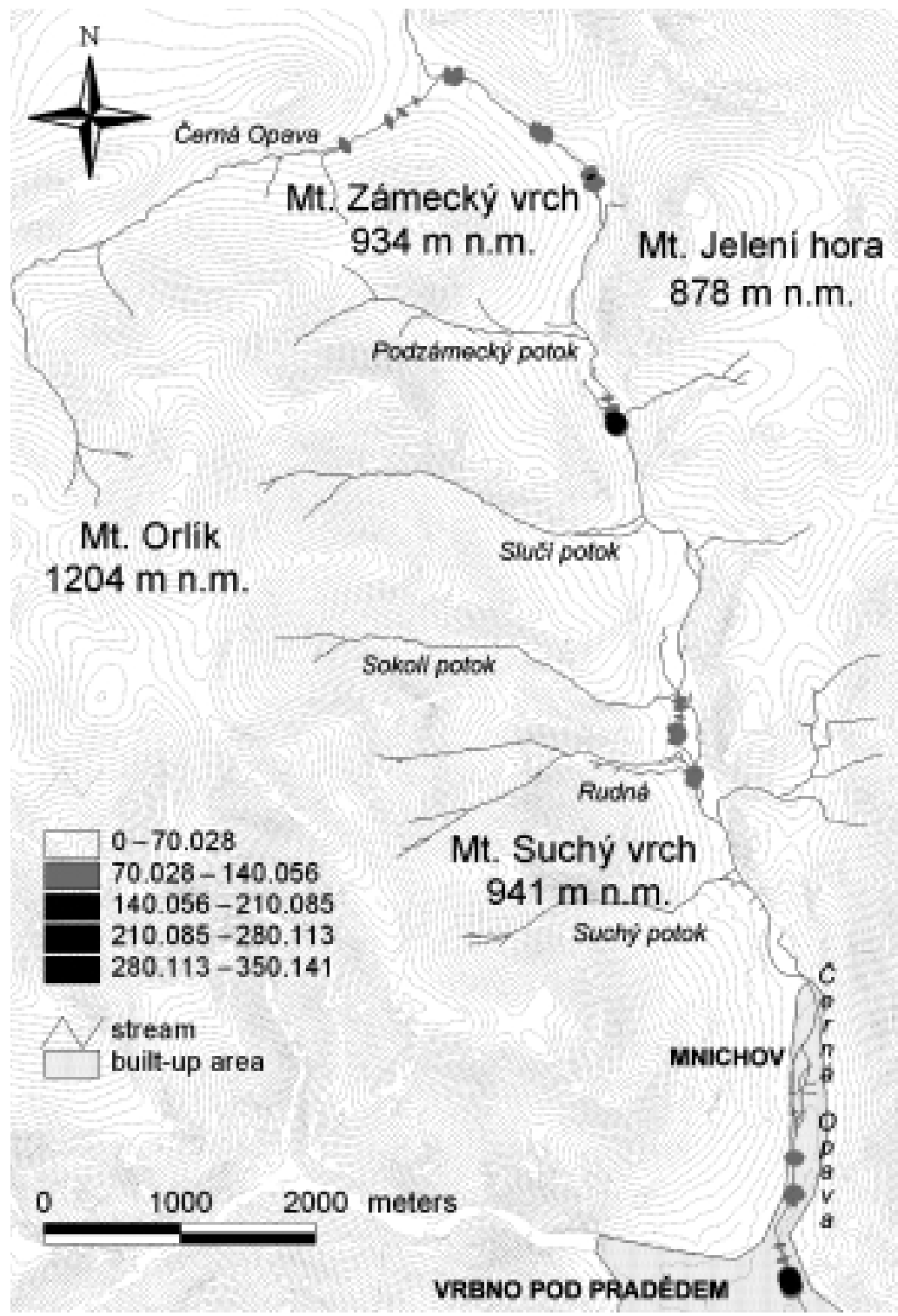

Figure 1: Density of "before the flood bars" in Černá Opava River (number of bars per km² with radius $100 \mathrm{~m}$ )

nameless brook in Drakov in the sector between Sokolí potok Brook and Rudná Brook and in lower part of the flow by confluence with Střední Opava River. The highest densities of "new bars after flood" (Fig. 2) are concentrated in the upper part of Černá Opava River - to the north from Zámecký vrch Hill in the area above and under the mouth of Podzámecký potok Brook, by the mouth of Slučí potok Brook, above Sokolí potok Brook and by the mouth of sinistral nameless brook above Mnichov. From 


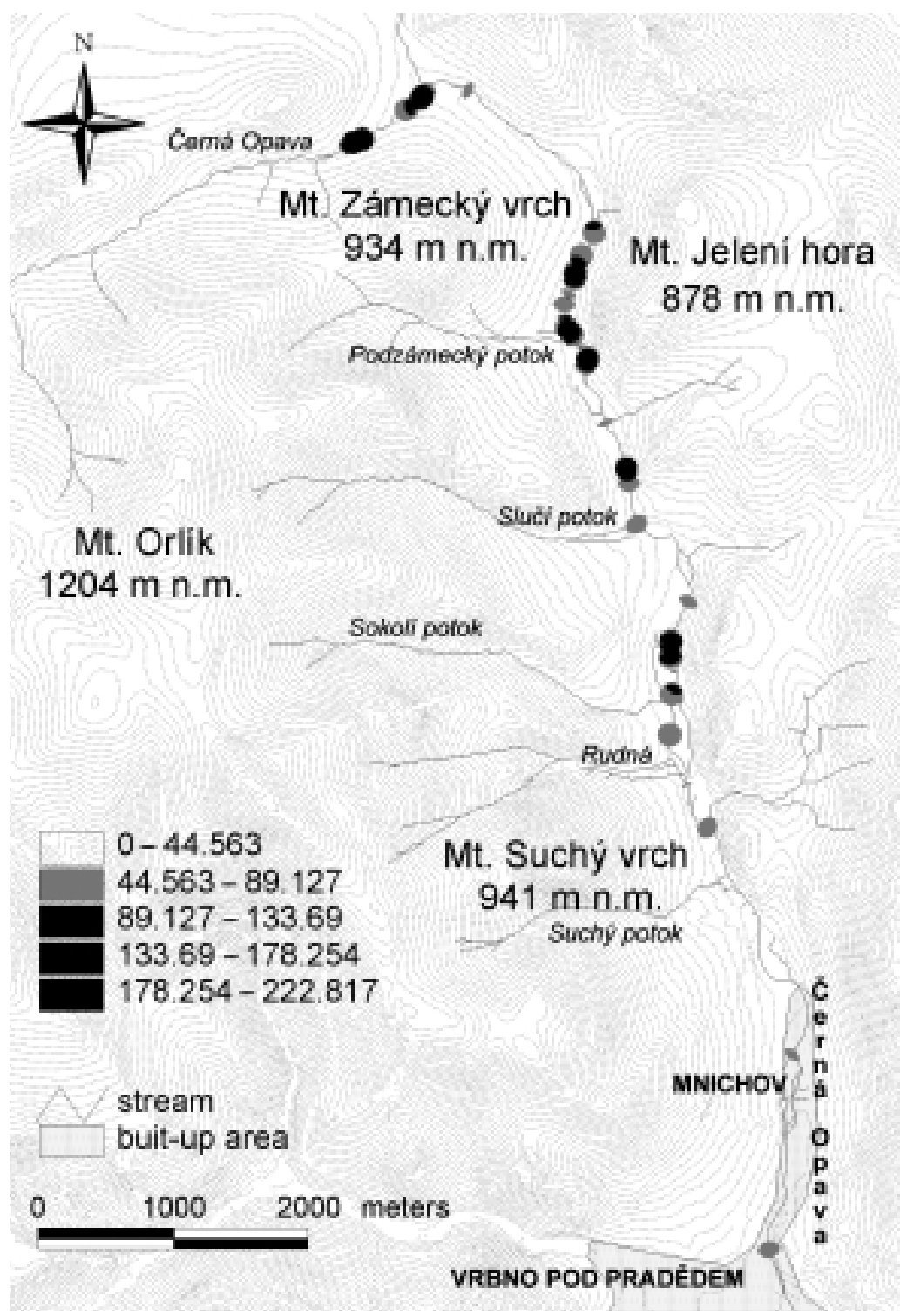

Figure 2: Density of "new after flood bars" in Černá Opava River (number of bars per km² with radius 100 m)

the perspective of position change of channel bars, no trend can be observed in general (Fig. 3). It is apparent that "new bars after flood" have the highest percentage representation in partial sections 1, 2, 3, 4, 5 from all other groups of channel bars. On the contrary their occurrence is sporadic in other sections excluding 13, 35 and 45. All groups of channel bars identically in border sections 1, 12, 45 a 5 (Table 1) show the highest percentage representation. 


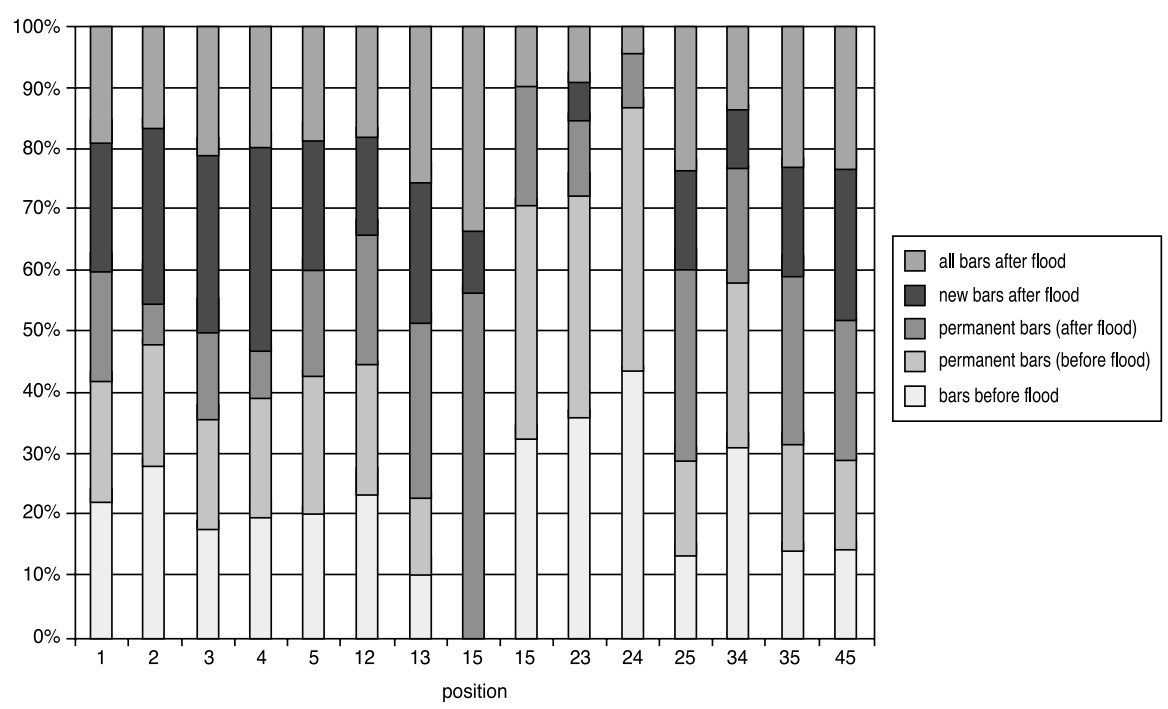

Figure 3: Proportional representation of single groups of bars in single cross-section profile of the channel "all bars after flood" - represent all bars existing after the flood; "new bars after flood" - represent all bars which were created after the flood and did not exist before the flood; "permanent bars after flood" - represent all bars existing before and after the flood, only after flood characteristic values are taken into account; "permanent bars before flood" - represent all bars existing before and after the flood, only after flood charakteristic values are taken into account "bars before the flood" - represent all bars which existed before the flood

From the perspective of connection of channel bars with banks it is evident that higher ratio of "bars before the flood" was without connection and after the flood ratio of bars with connection increased (Fig. 4). This ratio is noticeable especially in group

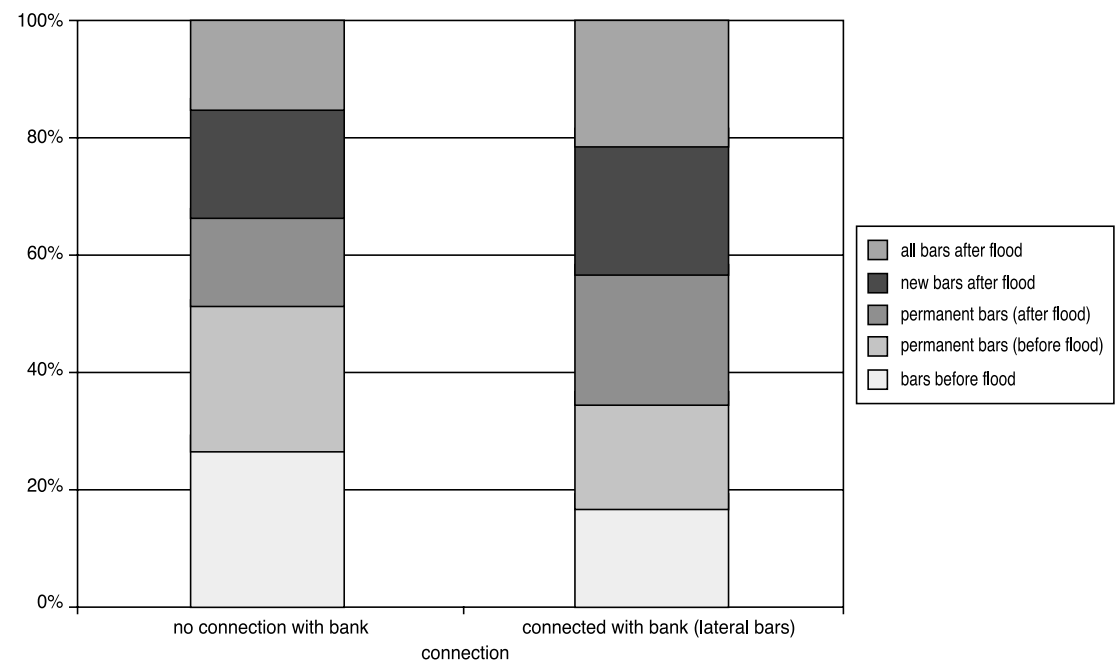

Figure 4: Proportional representation of single groups of bars from the viewpoint of connection with banks 


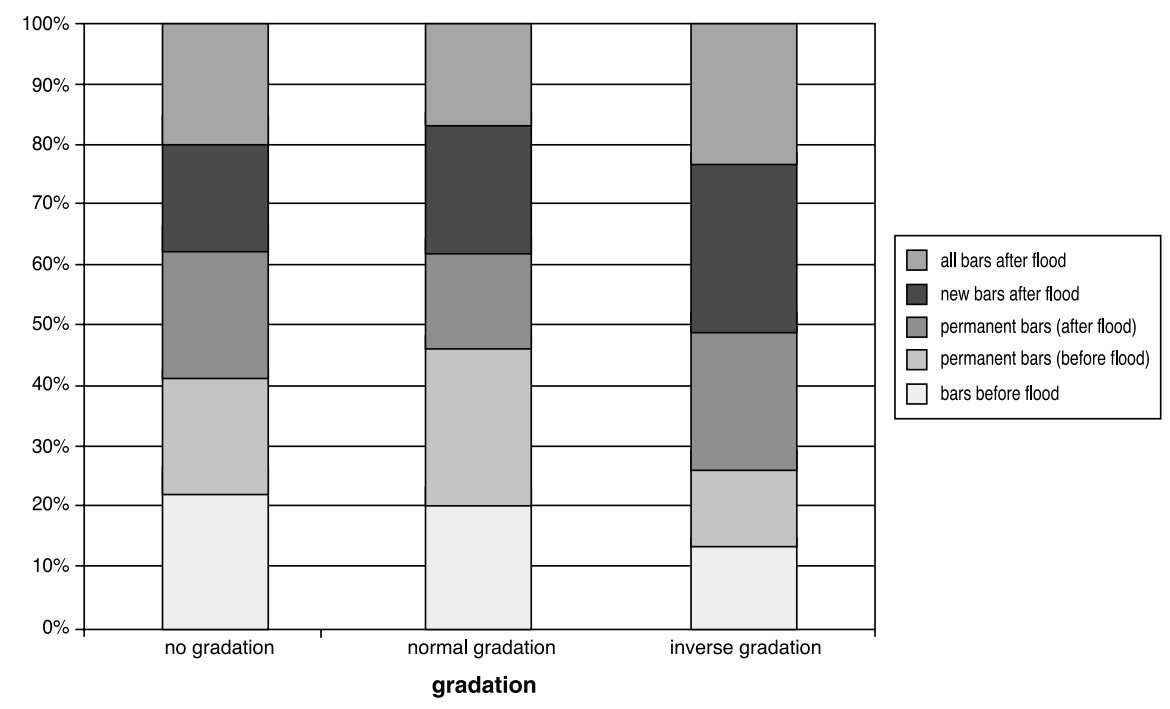

Figure 5: Proportional representation of single groups of bars from the viewpoint of gradation (normal gradation, it means configuration of sediments from more rough to fine-grained; inverse gradation, it means disposition of sediments from fine-grained to more rough)

of "bars before the flood" versus "all bars after flood" and "permanent bars before flood" versus "permanent bars after flood".

As concerns the gradation, we can say that representation of groups of channel bars is more or less even for bars without gradation and with normal gradation (Fig. 5), normal gradation predominates in "permanent bars before flood" and forms without

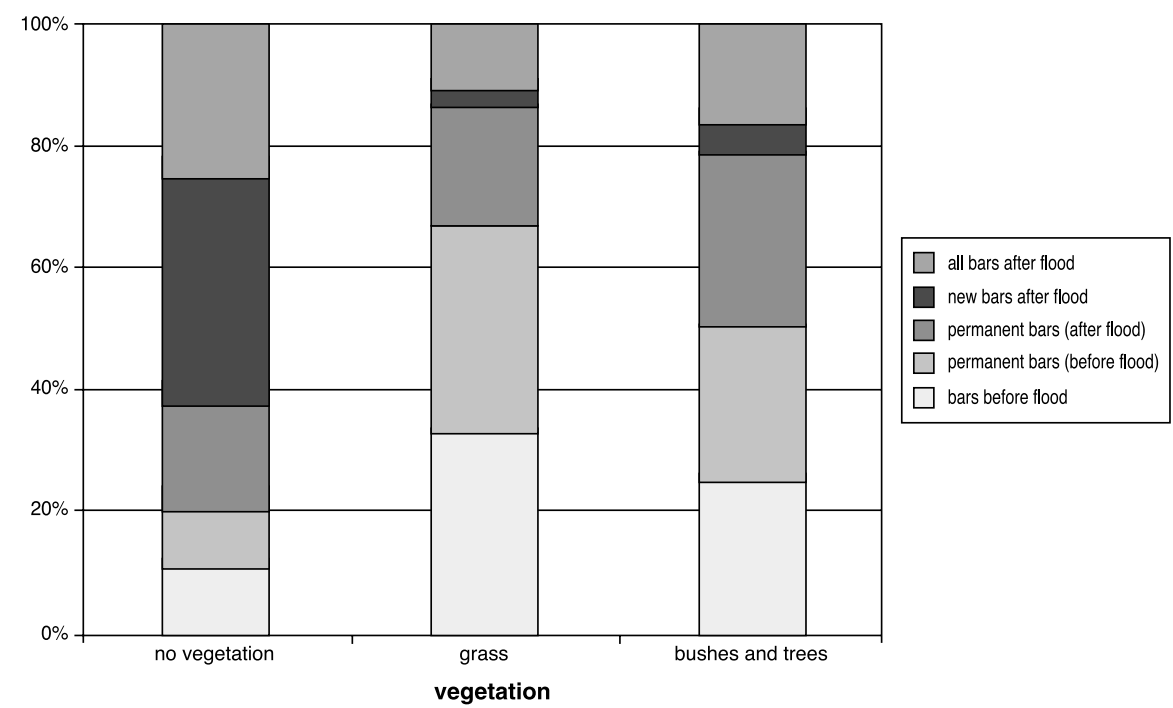

Figure 6: Proportional representation of single groups of bars from the perspective of vegetation coverage 
gradation predominate in "permanent bars after flood". All groups of channel bars, formed after the flood, contain higher number of bars with inverse gradation.

From the viewpoint of vegetation cover channel bars without vegetation predominate as expected in groups of bars which were created by the flood (Fig. 6). Grass cover predominates on channel bars created before the flood. It is similar for channel bars covered by bushes and trees.

\section{Correlation of characteristics of channel bars and ANOVA analysis}

Relation between single characteristics of channel bars is presented in Table 2 and 3. Significant correlation coefficients show that those demonstrating middle power of association predominate (sensu Hendl 2004). The length and width (before and after the flood) show the highest rate of correlation within all channel bars. Expected dependency appeared between width of the channel before the flood and other length characteristics of channel bars. The group of "permanent" bars has the expected positive dependence between some length characteristics such as between length and width of channel bars (for the period before the flood and after the flood and between themselves (Table 3)). It also turned out that all surveyed pre-flood characteristics correlate significantly with corresponding ones after the flood. The highest power of association in this group of channel bars have: width of stream 0.97 , vegetation 0.75 , position before (ifo) bend 0.95 and position behind bend 1 .

Variation analysis of studied characteristics for all channel bars shows that due to the flood conclusive changes of width of the channel occurred in areas where there are

width of stream $F(1.244)=5.7444, p=.01729$

length $F(1.244)=7.1108, p=.00817$

Vertical bars denote 0.95 confidence intervals

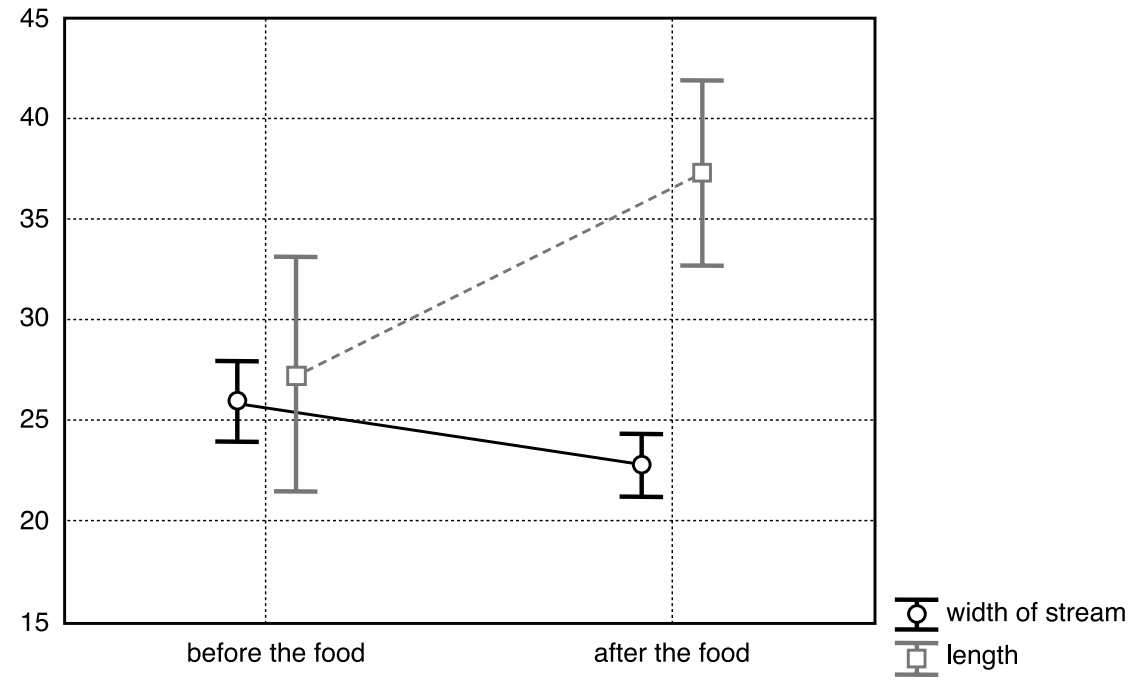

Figure 7: Variation analysis (one-way ANOVA) of channel width (where channel bar is situated) and its length due to the flood. All bars are considered 


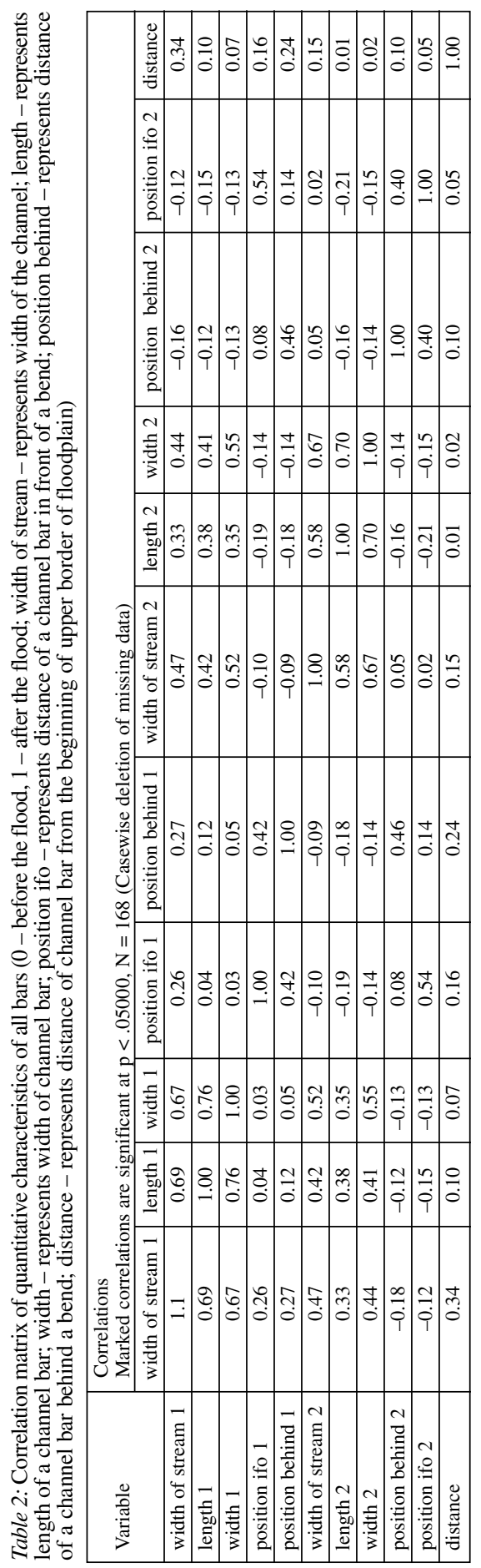

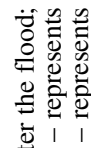

동다

$\therefore$ 으웜

ठี่نี

要: :

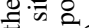

는

흉ㅎㅁ형

늘

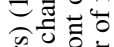

ปี⿻ ㇉己

농

屯

피를

氙吉

坖宁.

응.

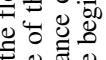

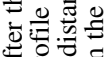

흘

㱐造

응 苍远

○ี 1 政

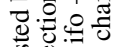

象

들

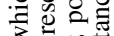

른.

औ 10

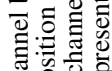

흉융

पैं

氚忐记

क 둥

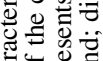

는

들

渮言.

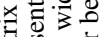

อี

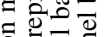

일

흥 㖊

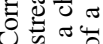

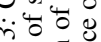

흘

월을

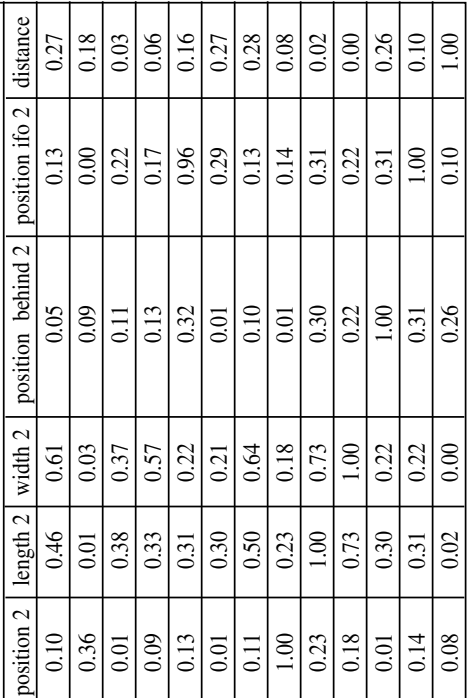

ง

ชิ

苟倍

:

tᄂ

흘

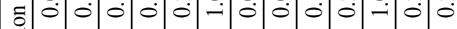

勇

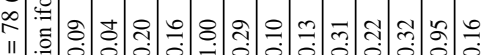

z :

ㅇ.

v v 言

$z=$

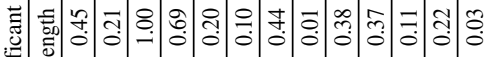

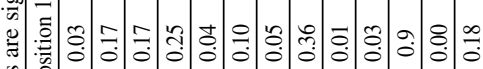
:

竞

言 $\begin{gathered}0 \\ 0\end{gathered}$

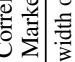

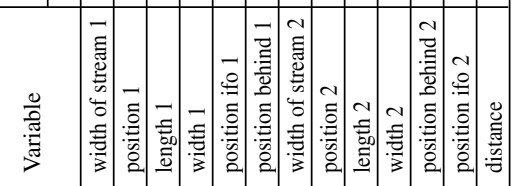




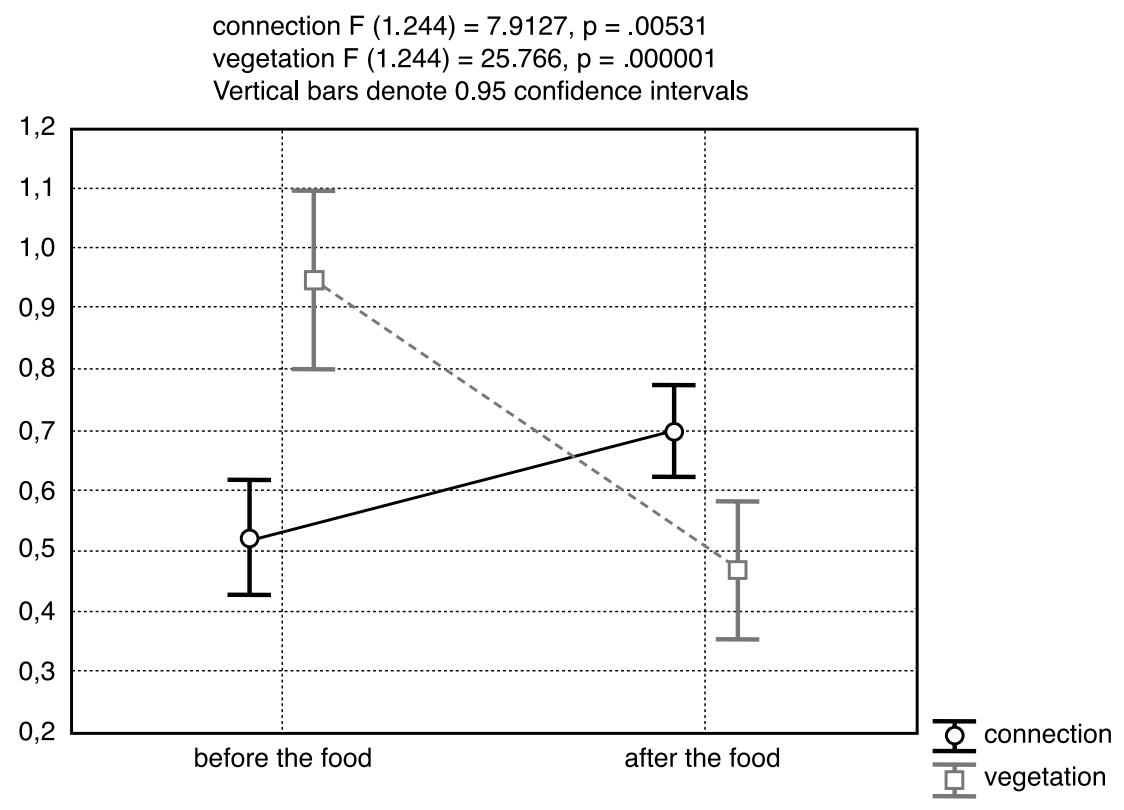

Figure 8: Variation analysis (one-way ANOVA) of connection of channel bars with banks and vegetation coverage of channel bars due to the flood. All bars are considered

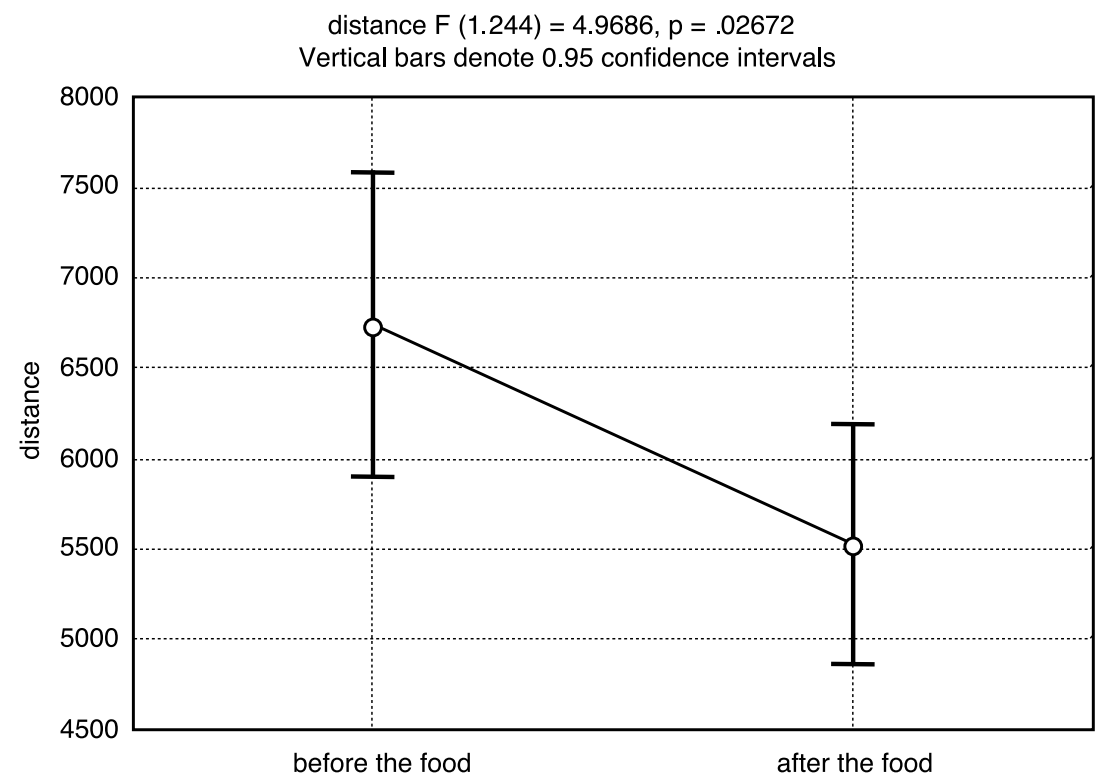

Figure 9: Variation analysis (one-way ANOVA) of channel bars' distance from the beginning of floodplain due to the flood. All bars are considered 
bars, and also in length of bars (Fig. 7), in connections of bars with banks, in vegetation cover of bars (Fig. 8) and in distance of bars from beginning (upper part) of floodplain (Fig. 9). Analysis of variation showed that due to the flood conclusive changes in group of "permanent" bars occurred in length $(\mathrm{F}=10.947 ; \mathrm{p}=0.00117)$, width $(\mathrm{F}=5.0018$; $\mathrm{p}=0.02676)$ and connection of bars with banks $(\mathrm{F}=5.5 ; \mathrm{p}=0.02029)$. Average length of channel bars increased in this group of "bars after the flood" from $30 \mathrm{~m}$ before the flood ( 0.95 confidence interval $23-37 \mathrm{~m})$ to $46 \mathrm{~m}$ ( 0.95 confidence interval $38-53 \mathrm{~m})$. Average width of channel bars increased in this group of "bars after the flood" from $4.5 \mathrm{~m}$ before the flood ( 0.95 confidence interval $3.1-6 \mathrm{~m})$ to $6.9 \mathrm{~m}$ ( 0.95 confidence interval $5.4-8.3 \mathrm{~m})$. Likewise a number of channel bars connected with bank increased by $45 \%$ after the flood.

\section{Discussion}

\section{Density and changes between groups of channel bars}

A number of localities with the highest density of channel bars in the course of upper and middle part of floodplain of Černá Opava River increased after the flood (Fig. 10). The most noticeable increase of density is around Zámecký vrch Hill and above and under the mouth of Sokolí potok Brook. In the lower part of Černá Opava River localities with higher density were preserved but their number did not grow and moreover values of density fell from $280-350$ to $140-210 \mathrm{bars} / \mathrm{km}^{2}$ in radius $100 \mathrm{~m}$. Spatial distribution of channel bars (higher density values in localities of bends or mouths of side flows) can be explained by slower flow (Abad et al. 2008, Bridge 2003) actually change of longitudinal profiles in these localities. This placement rule is valid for channel bars which were created before and after the flood.

Influence of roughness of banks appears in the same extent in channel bars which were created before the flood and "new bars after the flood". It is represented by similar and the highest percentage ratio of channel bars in sections of channel neighboring with banks $(1,12,45,5$; Table 1$)$. If we define a stabile section by the situation that all groups of channel bars have percentage representation between 10-30\% (every group of channel bars would have $20 \%$ of the section in case no change in the section occurs). Thus, as the stable parts of the channel can be described sections No. 1, 3, 5, 12, 13, 35, 34 and 45 (Fig. 3). Roughly one half of existing channel bars with no connection with banks was transformed into bars with connection with banks after the flood (above all lateral bars and point bars). Among "new bars after flood" predominate also those with connection with banks. It can be explained by the fact that the already existing channel bars become large barriers during the flood (sensu Darby, Thorne 1996; Bridge 2003) and they bond with other fluvial material which connects the channel bars with banks. Evaluation of spatial distribution changes shows that connection with a bank occurred more often in channel bars reaching into more sections of channel where proportion representation of these sections increases especially in "permanent bars after flood" (sections: 13, 14, 25, 35, 45). The rate fall of midchannel bars indicates that bed material is not too coarse to be carried and the volume of material is not too great to be transformed (sensu Brierly, Fryirs 2005, 


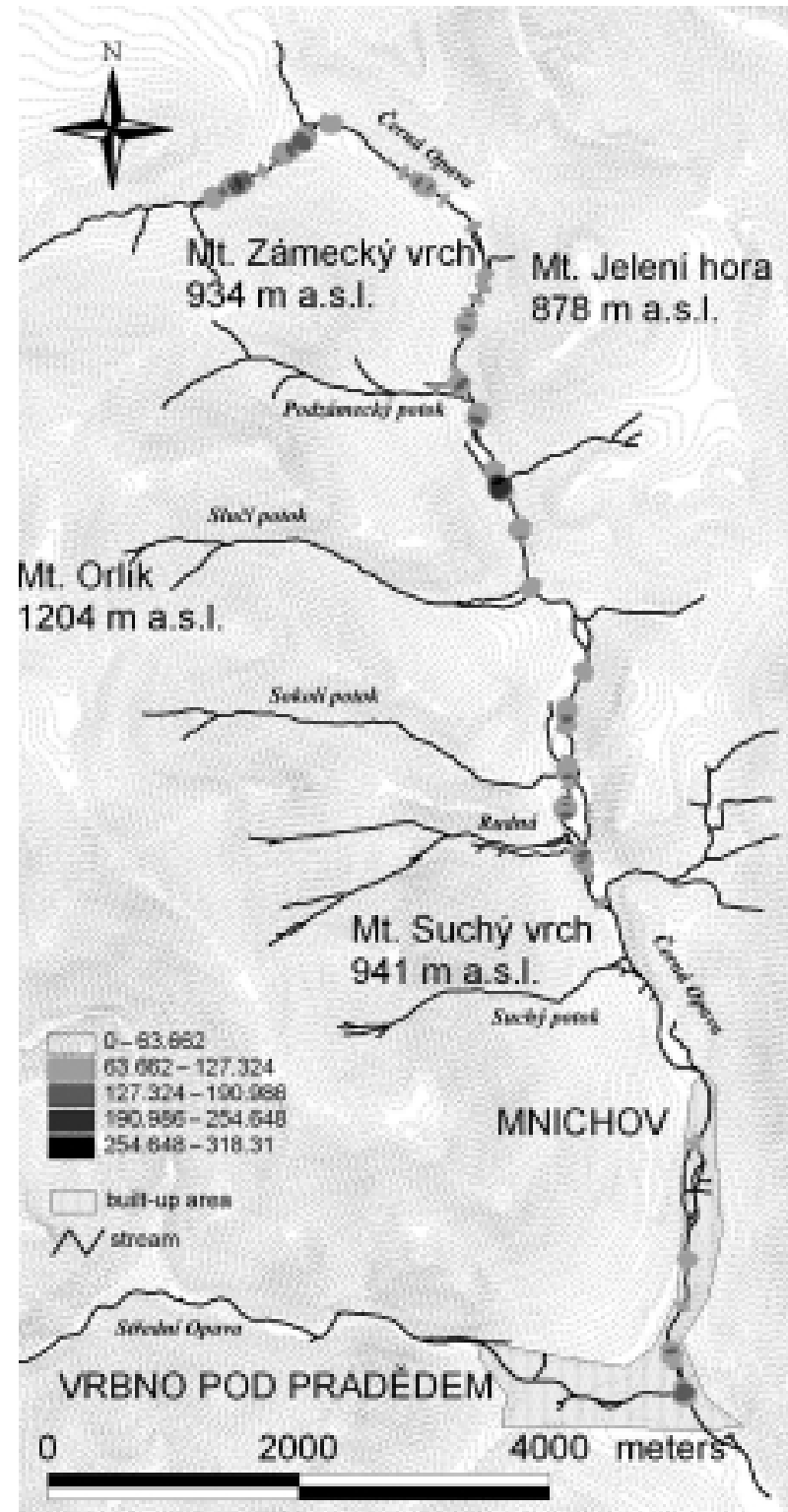

Figure 10: Density of "all after flood bars" in Černá Opava River (number of bars per km² with radius $100 \mathrm{~m}$ )

p. 169). Increased part of "new bars after flood" with inverse gradation proves more complicated and faster flow (Richards, Clifford 1991) and following related sedimentation. During the flood, older channel bars were simultaneously modified and transformed onto bars without gradation or more often with inverse gradation. Type of vegetation cover shows expected fact: that channel bars covered with vegetation are 
typicall for the "before the flood bars". The ratio of "before the flood bars" (Fig. 6) is larger for channel bars covered with grass than for those covered with bushes and trees. This corresponds with the fact that there are more "new bars after flood" covered with bushes and trees than those covered with grass. The reason is that channel bars covered with bushes and trees are mainly larger and with more rough surface. These bars with bushes and trees were disintegrated (sensu Popov 1962 in Schumm 2005) during the flood and thus several new channel bars were created out of it.

\section{Correlation of channel bars characteristics and ANOVA analysis}

When interpreting correlation coefficient for all groups of channel bars it is important to realize that if a bar disappeared during the flood or appeared after the flood, its attributes for state after the flood, actually before the flood, equal zero. This is the reason for lower values of correlations showing within the group of all bars. On the contrary, for the group of "permanent" bars, from the viewpoint of the same register, both qualitative binary and ordinal attributes (before and after the flood) can be evaluated mutually.

The fact that corresponding attributes (before and after the flood) positively correlate together with middle power of association (Tab. 2, 3) shows, that the "preflood bars" influence the evolution of the "after-flood bars" (proper transformation and creation of new channel bars). It is particularly true for length and width of channel bars where correlation coefficients for group of all bars correspond to coefficients of "permanent" bars. High power of association of "permanent" bars (Tab. 3) between the pre-flood and after-flood width of channel (0.97), position before the bend (0.95) and behind the bend (1) shows that no noticeable changes of position occurred for this group of channel bars regarding the flood.

There is a positive significant relationship between channel bars covered by trees and shrubs and the length and width of these bars ("before and after the flood"). These bars are significantly bigger than other ones. It shows a stabilizing function of vegetation (shrubs and trees) due to bars, thanks to which these bars can grow. On the contrary surrounding banks are exposed to increased erosion which widens the former channel. Channel bars with grass cover did not have similar relationship with length and width of bars. Ashworth (1994) presents similar findings. Stabilizing role of vegetation was described also by Hey and Thorne (1986) but these authors take into account only impact of vegetation on banks therefore on width of channel where channel width was greater when trees and shrub were lacking. Huang and Nanson (1997) showed, that possible range of variation in channel width caused by bank vegetation is less than the one caused by channel bed vegetation. Because these two act in opposite directions, the influence of bank vegetation on channel width, in certain circumstances, can be overridden by that one of channel bed vegetation, resulting in wider channels. The established positive dependence (significant ANOVA test) between channel width and vegetation cover of channel bars corresponds to it, whereas the major part of the river flows through forested area with banks fixated by trees and bushes. Negative correlation with middle power of association between length of the "after the flood bars" and placement before and behind the bend (before and after the flood) is also interesting (Tab. 3). It means that the shorter is the distance of channel bar from a bend, the more its length grows after flood. It shows an important function 
of channel bars as natural barriers (sensu Wilson, Horritt 2002) in the channel which in connection with bends effect bond with other sediments during a flood. In other words the channel bars in proximity of bends indicate places in the channel where an increased accumulation will occur during a flood. On the contrary sediment of bars, which are placed in further from the bends, is carried away and thus areas of channel bars decrease. This is apparently a result of higher speed which water reaches in further from bends. It has been observed that there is almost no coarse material of channel bars supply from hillslopes, indicating that bedload comes mostly from channel itself. That is like as Aragón River in Spain (Lana-Renault, Reuiés 2007).

Significant changes (increase) of width and length of "permanent" bars show that the existing channel bars generally expanded during the flood. For example enlarged channel bars got connected with banks due to increase of their length and width. Withal no significant change of position in the channel occurred in this group of channel bars. It can have connection with their relation to large blocks which are part of gravel bedload as Owczarek (2008) described for Střední Opava River. Significant decrease of channel width within all channel bars, which is clear from ANOVA analysis, can be explained by increased number of channel bars in the upper part of stream and by stagnation or moderate decrease of number of bars in the lower part of stream (floodplain) where the channel is wider (Fig. 10). Increased length of channel bars is reflecting continuing sedimentation on already existing bars. It also proves increase of the same attribute of "permanent" bars. Ashworth (1996) proved that length of midchannel bars increases with growing average speed of flow which would correspond to the faster flood flow. It is also proved by increased number of channel bars connected with banks (lateral banks, see above). Decrease of quality of a vegetation cover is expected as new channel bars are not covered by vegetation. Moreover a vegetation cover had been swept away frequently during the flood. Significant decrease of distance from the upper part (begging) of floodplain relates to change of width of channel and indicates that number of channel bars in the upper and middle part of floodplain of Černá Opava River increased enormously.

\section{Conclusion}

During the September 2007 flood number of channel bars changed, as well as a lot of surveyed characteristics of channel bars:

1. Number of channel bars increased mainly in the upper part of floodplain of Černá Opava River.

2. The flood caused a significant increase of channel bars length and increase of number of channel bars connected with the banks. Moreover width of "permanent" bars increased significantly too.

3. Roughness of the banks has the same effect during the flood as well as standard water level.

4. As a consequence of large amount of new channel bars total coverage by vegetation decreased. At the same time the existing vegetation cover was damaged and it was overlaid by new fluvial sediments. 
5. An impact of vegetation on channel bars on channel enlargement is greater than a stabilization role of bank vegetation. On the other words erosion power of river accelerated by channel bars vegetation is greater than stabilizing effect of bank vegetation.

6. Spatial distribution of "permanent" bars was not significantly changed. Thus, these channel bars indicate spots of increased flood sedimentation in the channel. In other words channel bars in vicinity of bends (for example scroll bars or point bars) indicate parts of the channel where higher accumulation will regularly occur during a flood. On the contrary, the channel bars (such as lateral bars) which are further from the bends are being washed away and consequently shortened.

7. Faster and more complicated flow during the flood enables creation of new bars with inverse gradation.

\section{Acknowledgements}

This contribution was financially supported by MŽP ČR (Ministry of Environment of the Czech Republic), project VaV SM/2/57/05 "Long-term changes in fluvial ecosystems in floodplains affected by extreme floods" and research project "Geographical Systems and Risk Processes in the Context of Global Changes and European Integration” (MSM 0021620831).

\section{Literature}

ABAD, J.D., BUSCAGLIA, G.C., GARCIA, M.H. (2008): 2D stream hydrodynamic, sediment transport and bed morphology model for engineering applications. Hydrological Processes, 22, pp. 1443-1459.

ASHWORTH, P.J. (1996): Mid-channel bar growth and its relationship to local flow strength and direction. Earth surface processe and landforms, 21, pp. 103-123.

BARRY, J.J. (2004): A general power equation for predicting bed load transport rates in gravel bed rivers. Water Resources Research 40, W10401.

BATALLA, R.J., MARTÍN-VIDE, J.P. (2000): Threshold of particle entrainment in a poorly sorted sandy gravel-bed river. Catena, 44, pp. 223-243.

BRIDGE, J.S. (2003): Rivers and floodplains. Blackwell. Oxford, 491 p.

BRIERLEY, G.J., FRYIRS, K.A. (2005): Geomorphology and river management. Blackwell, Oxford, 398 p.

CZUDEK, T. (1997): Reliéf Moravy a Slezska v kvartéru. Sursum, Brno, 213 p.

DARBY, S.E., THORNE, C.R. (1996): Development and testing of riverbank stability analysis. Journal of Hydraulic Engineering, 122, pp. 443-454.

DEMEK, J. (ed.) et al. (1987): Hory a nížiny, Academia, Praha. 584 p.

DOLLAR, E.S.J. (2004): Fluvial geomorphology. Progress in Physical Geography 28,3 pp. 405-450.

FERGUSON, R.I. (1994): Critical discharge for entrainment of poorly sorted gravel. Earth Surface Processes and Landforms, 19, pp. 179-186.

GARCÍA, C., LARONNE, J.B., SALA, M. (2000): Continuous monitoring of bedload flux in a mountain gravel-bed river. Geomorphology 34, pp. 23-31.

HARDY, R.G. (2006): Fluvial geomorphology. Progress in Physical Geography, 30, 4, pp. 553-567.

HEY, R.D., THORNE, C.R. (1986): Stable channels with mobile gravel beds. Journal of Hydraulic engineering, 112, pp. 671-689.

HENDL, J. (2004): Přehled statistických metod. Portál. Praha, 583 p.

HLADNÝ, J. et al. (1998): Vyhodnocení povodňové situace v červenci 1997, MŽP, Praha, 163 p. 
HRÁDEK, M. (1999): Geomorphological aspects of the flood of July 1997 in the Morava and Oder basins in Moravia, Czech Republic. Studia Geomorphologica Carpatho-Balcanica, 33, pp. 45-66.

HRÁDEK, M. (2002): Změny v říčních korytech a nivách po povodni. In: Krajina, lidé a povodně v povodí řeky Moravy, A.Vaishar (ed.), ÚGN AV ČR, Brno, pp. 70-76.

HRÁDEK, M. (2005): Changes in the channels and floodplains of Sudetic rivers in the Morava river basin after the flood in July 1997. In: A. Szponar and S. Horska-Schwarz (eds.): The spatial-functional structure of landscape. The problems of landscape ekology, vol. XVII, Polish association for landscape ekology, Wróclaw, pp. 226-231.

HUANG, H.Q., NANSON, G.C. (1997): Vegetation and channel variation; a case study of four small streams in southeastern Australia. Geomorphology, 18, pp. 237-249.

KLIMEK, K., MALIK, I., OWCZAREK, P., ZYGMUNT, E. (2003): Climatic and human impact on episodic alluviation in small mountain valleys, the Sudetes. Geographia polonica, 76, 2, pp. 55-64.

KLIMEK, K., ZIELIŃSKA, M. (2006): Mid-mountain slopes clearence as a cause of small channel pattern transformation (a case study from Černá Opava Catchment, Eastern Sudetes). In: Geomorfologické výzkumy v roce 2006, Smolová, I. (ed.), UP Olomouc, ČAG, Olomouc, pp. 107-111.

KŘÍŽEK, M. (2003): Geomorfologický výzkum - In: Vilímek,V., Langhammer, J., Šefrna, L., Lipský, Z., Křížek, M., Stehlík, J.: „Posouzení efektivnosti změn ve využíuání krajiny pro retenci a retardaci vody jako preventivní opatření před povodněmi “. Závěrečná zpráva $\mathrm{k}$ vládnímu projektu - Vyhodnocení katastrofální povodně v srpnu 2002, Praha: Přf UK, pp. 17-23.

KŘÍŽEK, M. (2007a): Údolní niva jako geomorfologický fenomén. - In: Langhammer, J. (ed.): „Povodně a změny v krajině“, Praha: $\mathrm{P} 3 \mathrm{~K}$, pp. 217-229.

KŘÍŽEK, M. (2007b): Prostorové uspořádání popovodňových korytových akumulací Sázavy. - In: Langhammer, J. (ed.): „Změny v krajině a povodňové riziko “, Praha: Přf UK, pp. 153-161.

LANA-RENAULT, N., REÜÉS, D. (2007): Bedload transport under different flow conditions in a humandisturbed catchment in the Central Spanish Pyrenees, Catena, 71, pp. 155-163.

MARTIN, Y. (2003): Evaluation of bed load transport formulae using field evidence from the Vedder River, British Columbia. Geomorphology, 53, pp. 75-95.

OWCZAREK, P. (2008): Hillslope deposits in gravel-bed rivers and their effects on the evolution of alluvial channel forms: A case study from the Sudetes and Carpathian Mountains. Geomorphology, 98, pp. 111-125.

POLÁCH, D., GÁBA, Z. (1998): Historie povodní v šumperském a jesenickém okrese, Severní Morava, 75, pp. 3-29.

RICHARDS, K.S., KLIFFORD, N.J. (1991): Fluvial geomorphology - structured beds in gravelly rivers. Progress in physical geography, 15, pp. 407-422.

ROSGEN, D.L. (1994): A classification of natural rivers, Catena, 22, pp. 169-199.

SCHUMM, S.A. (1985): Patterns of alluvial rivers. Annual Review of Earth and Planetary Sciences, 13, pp. 5-27.

SCHUMM, S.A. (2005): River variability and complexity. Cambridge university Press, Cambridge, 220 p.

WILSON, C.A.M.E. AND HORRITT, M.S. (2002): Measuring the flow resistance of submerged grass. Hydrological Processes 16, pp. 2589-2598.

Résumé

Důsledky povodně v září 2007 na uspořádání korytových akumulací na Černé Opavě

Korytové akumulace představují fluviální uloženiny v prostoru koryta protékaného vodním tokem. Jsou typické pro místa, kde dochází ke zpomalení unášecí schopnosti vodního toku. Tedy korytové akumulace vypovídají o chování toku v daném úseku koryta (Bridge 2003; Křǐžek 2007a). Cílem tohoto článku je charakterizovat základní polohové, ale i kvalitativní změny korytových akumulací (vzniklých před povodňovou situací) za podmínek normálního průtoku a za povodňového stavu.

Černá Opava je nejdelší ze tř̌i zdrojnic řeky Opavy. Výzkum byl prováděn na 13,5 km dlouhém úseku, kde má Černá Opava vyvinutou údolní nivu, tj. od mostu pod Předním Jestřábím (744,9 m n.m.) až do Vrbna pod Pradědem po soutok se Střední Opavou (540 m n.m.). 
Během dvou mapovacích kampaní bylo ve studovaném území nalezeno 168 korytových akumulací, přičemž 94 bylo zjiššeno před povodní (po povodni z nich zbylo 78) a 74 je nově vzniklých po povodni. Celkově však po povodni zůstalo 152 korytových akumulací. Největší hustoty předpovodňových korytových akumulací (obr. 1) jsou dosaženy v zákrutech pod Zámeckým vrchem, při vyústění levostranného bezejmenného potoka na Drakově, $v$ úseku mezi Sokolím potokem a Rudnou a v dolní části toku při soutoku se Stř̌ední Opavou. U nově vzniklých korytových akumulací jsou nejvyšší hustoty (obr. 2) soustředěny do horní části Černé Opavy - severně od Zámeckého vrchu, do úseku nad i pod vyústěním Podzámeckého potoka, při vyústění Slučího potoka, nad Sokolím potokem a při ústí levostranného bezejmenného potoka nad Mnichovem.

Kromě početního nárůstu korytových akumulací se měnily mnohé ze sledovaných charakteristik korytových akumulací:

1. Došlo k nárůstu počtu korytových akumulací především v horní části údolní nivy Černé Opavy.

2. Povodeň způsobila signifikantní nárůst délky korytových akumulací a nárůst počtu korytových akumulací spojených se břehy. Navíc u korytových akumulací existujících před i po povodni (tzv. permanent bars) se signifikantně zvětšila i jejich šiřrka.

3. Drsnost břehů má stejný efekt během povodně i mimo povodeň.

4. V důsledku velkého počtu nově vzniklých akumulací se snižilo celkové pokrytí vegetací. Zároveň však docházelo i k poničení stávajícího vegetačního krytu a jeho překrytí novými fluviálními sedimenty.

5. Účinek vegetace na channel bars na rozšiření koryta je větší než stabilizační účinek bank vegetation. Jinými slovy channel bars vegetation akcelerovaná erozní působení toku na břehy je větší než stabilizační síla břehové vegetace.

6. U korytových akumulací, které existovaly před i po povodni nedošlo k signifikantní změně polohy. Tedy tyto akumulace ukazují místa v korytě, která jsou lokalitami zvýšené povodňové akumulace. Jinými slovy, korytové akumulace v blízkosti zákrutů ukazují místa v korytě, kde bude během povodně zvýšená akumulace. Naopak u korytových akumulací, které se nacházejí ve větších vzdálenostech dochází k odnosu materiálu a jejich následnému zkracování.

7. Rychlejší a složitější proudění během povodně dává vzniknout korytovým akumulacím s opačnou gradací.

Marek Krǐžek

Charles University in Prague, Faculty of Science Department of Physical Geography and Geoecology

Albertov 6 ,

12843 Prague 2

Czech Republic

e-mail: krizekma@natur.cuni.cz 